\title{
Compositions of Surface Layers Formed on Amalgams in Air, Water, and Saline
}

\author{
Takao HANAWA, Bruce E. GNADE ${ }^{1}$, Jack L. FERRACANE ${ }^{2}$, \\ Toru OKABE ${ }^{3}$ and Fumio WATARI \\ Department of Dental Materials and Engineering, Hokkaido University School of Dentistry, \\ Kita 13 Nishi 7, Kita-ku, Sapporo 060, Japan \\ ${ }^{1}$ Materials Science Laboratory, Texas Instruments, Dallas, TX 75265, USA \\ ${ }^{2}$ Department of Dental Materials Science, The Oregon Health Science University, \\ School of Dentistry, Portland, OR 97201, USA \\ ${ }^{3}$ Department of Biomaterials Science, Baylor College of Dentistry, Dallas, TX 75246, USA
}

Received May 31, 1993/Accepted October 15, 1993

\begin{abstract}
The surface layers formed on both a zinc-free and a zinc-containing dental amalgam after polishing and aging in air, water, or saline, were characterized using $x$-ray photoelectron spectroscopy (XPS) to determine the compositions of the surface layers which might govern the release of mercury from amalgam. The XPS data revealed that the formation of the surface layer on the zinc-containing amalgam was affected by the environment in which the amalgam was polished and aged, whereas that on the zinc-free amalgam was not affected. In addition, among the elements contained in amalgam, zinc was the most reactive with the environment, and was preferentially dissolved from amalgam into water or saline. Mercury atoms existed in the metallic state in the surface layer.
\end{abstract}

Key words: Dental amalgam, Surface layer, Environment

\section{INTRODUCTION}

Dental amalgams have surface oxide layers. The surface layer formed on aged zinccontaining amalgams was found to primarily be composed of a (hydrated) tin and zinc oxy -hydroxide while that on aged zinc-free amalgams consisted essentially of tin oxide ${ }^{1)}$. In addition, zinc was the most significant element in determining the nature of the surface layer formed on amalgam ${ }^{1}$.

The surface oxide layers play an important role in retarding the release of mercury from amalgams. In one study, mercury emission from amalgam was essentially terminated within approximately $1 \mathrm{~h}$ from the time the amalgam was abraded under dry conditions, due to the formation and growth of a surface oxide layer on the amalgam ${ }^{2)}$. In another study, amalgam specimens lost mass when they were heated to $130^{\circ} \mathrm{C}$ in an inert gas (argon) atmosphere ${ }^{3)}$, indicating that mercury evaporated from the amalgams. However, no appreciable mass loss occurred when the amalgams were heated to the same temperature in air ${ }^{3,4)}$. These results indicate that the formation and/or growth of a surface layer on the amalgam during heating in air retards the evaporation of mercury. In addition, the rate of release of mercury from freshly triturated amalgams has been shown to be elevated in argon, but declined dramatically once the specimens were exposed to air and oxidation could occur ${ }^{5}$. 
The presence of water vapor also contributed to the reduced rates of release. Other studies have shown that the rate of dissolution of ions from amalgams into saline was very low once the amalgam had set ${ }^{6,7)}$, and was possibly inhibited by the existence of a surface layer formed during immersion.

It is apparent that the surface oxide layer formed on amalgam affects the evaporation of mercury and the dissolution of elements into solution. Characterization of this surface layer is necessary for further evaluation of the mode of mercury release from amalgam. The purpose of this study was to investigate the differences in the composition of the surface layer formed on a zinc-free and zinc-containing amalgam under three environments (air, water, and saline) at $1 \mathrm{~h}$ after polishing. X-ray photoelectron spectroscopy (XPS) is most appropriate for this study, because XPS is suited for elemental analysis of surfaces, chemical state identification of surface species, and in-depth composition profiles of the elemental distribution in thin layers ${ }^{8)}$. It is believed that this information will enhance the understanding of the rearrangement of constituent elements on the surface of amalgam during aging in different environments.

\section{MATERIALS AND METHODS}

Amalgams were prepared using single composition high-copper alloys : a zinc-free alloy * and a zinc-containing alloy**. The chemical compositions of the alloys as well as those of the resultant amalgams, which were calculated using the amount of mercury employed, are summarized in Table 1. Amalgams were triturated for $16 \mathrm{~s}$ on an amalgam mixer\# set on M2 according to the manufacturer's recommendation and condensed into a $10 \mathrm{~mm} \times 10 \mathrm{~mm} \times 1$ $\mathrm{mm}$ stainless steel mold with a pressure of approximately $14 \mathrm{MPa}$ for $90 \mathrm{~s}$ from $30 \mathrm{~s}$ to 120 $\mathrm{s}$ after trituration, in accordance with the procedure outlined in ADA Specification No. 1.

The specimens were aged in air at $37^{\circ} \mathrm{C}$ for $7 \mathrm{~d}$ and subsequently polished using $\# 600$ grit $\mathrm{SiC}$ paper in air, deionized water, or $0.9 \% \mathrm{NaCl}$ aqueous solution (saline). During the polishing, approximately $50 \mu \mathrm{m}$ of amalgam was removed from the surface. After polishing, the specimens were kept for $1 \mathrm{~h}$ in the corresponding environments, $i$. $e$. air, water, or saline. The grinding debris left on the specimens after polishing was removed by a blow of compressed air, for the experiment in air. The specimens for the water and saline-experiments

Table 1 Chemical compositions of alloys and resultant amalgams

\begin{tabular}{|c|c|c|c|c|c|c|}
\hline \multirow{2}{*}{ Type } & & \multicolumn{5}{|c|}{ Composition (mass\%) } \\
\hline & & $\mathrm{Ag}$ & $\mathrm{Sn}$ & $\mathrm{Cu}$ & $\mathrm{Zn}$ & $\mathrm{Hg}$ \\
\hline Zn-free & Alloy & 56.0 & 29.0 & 15.0 & - & - \\
\hline amalgam & Amalgam & $30.2(36.4)^{*}$ & $15.7(17.2)$ & $8.1(16.6)$ & - & $46.0(29.8)$ \\
\hline $\mathrm{Zn}$-containing & Alloy & 56.0 & 27.5 & 15.0 & 1.5 & - \\
\hline amalgam & Amalgam & $30.2(36.2)$ & $14.8(16.1)$ & $8.1(16.5)$ & $0.8(1.5)$ & $46.1(29.7)$ \\
\hline
\end{tabular}

* Atomic percent given in the parentheses.

* Lumi Alloy, GC Corp., Tokyo, Japan

** Special-ordered alloy, GC Corp., Tokyo, Japan

\# Varimix II, L. D. Caulk, Milford, DE, USA 
were washed by deionized water after immersion. The specimens were then analyzed using XPS.

XPS spectra corresponding to Ag3d, Sn3d, Cu2p, Zn2p, Hg4f, Ols, Nals, Cl2p, and Cls of these specimens, were recorded using an $\mathrm{x}$-ray photoelectron spectrometer\# with the AlK $\alpha$ line (energy $1486.6 \mathrm{eV}$, voltage $13 \mathrm{kV}$, and current $20 \mathrm{~mA}$ ). The electron energy analyzer was operated in the constant analyzer energy mode at a pass energy of $20 \mathrm{eV}$. The binding energies measured were calibrated with those of $\mathrm{Au} 4 \mathrm{f}_{7 / 2}(84.0 \mathrm{eV})$ and $\mathrm{Cu} 2 \mathrm{p}_{3 / 2}(932.7 \mathrm{eV})$. Resolution with full width at half-maximum (FWHM) of the Au4f $\mathrm{f}_{7 / 2}$ peak was $1.1 \mathrm{eV}$ under the experimental conditions and the binding energies were measured with an accuracy of 0.1 $\mathrm{eV}$. The specimens were cooled below $-20^{\circ} \mathrm{C}$ with liquid nitrogen to maintain the vacuum in the specimen chamber, which otherwise would have been compromised by the pressure increase due to the emission of mercury vapor from the specimens during testing. The pressure in the specimen chamber during spectral acquisition was approximately $5 \times 10^{-8} \mathrm{~Pa}$.

The relative concentration of atom $i, C_{i}$, was calculated from the integrated intensity for the $i j$ electron (level $j$ of atom $i$ ), $I_{i j}$, and the atomic sensitivity factor of the $i j$ electron, $\mathrm{S}_{i j}$, according to the follwing equation :

$$
C_{i}=\left(I_{i j} / S_{i j}\right) /\left\{\Sigma\left(I_{k} / S_{k}\right)\right\}
$$

where $I_{k}$ and $S_{k}$ are the corresponding values for element $k$. Depth-profiles of the elemental concentrations for each specimen were obtained by argon-ion-sputtering. Oxygen was still detected even after argon-ion-sputtering for $2 \mathrm{~h}$ in a pre-experiment, because of the roughness of the polished surface. Therefore, the complete removal of oxygen, $i$. $e$. the complete removal of the surface oxide layer, was impossible. Thus, a final sputtering time of $21 \mathrm{~min}$ was chosen, because that was when the ratio of the integrated intensity of the oxide-statespectrum of tin to that of the metallic-state-spectrum became constant (see Fig. 8). Consequently, sputtering was performed for $3,6,9,12,15$, and/or 21 min to profile the depth of the surface layer. The sputtering was performed with a beam-current-density of $0.5 \mu \mathrm{A} / \mathrm{cm}^{2}$ and an accelerating voltage of $5 \mathrm{kV}$. The sputter rate was $1 \mathrm{~nm} / \mathrm{min}$ which was calculated according to the manufacturer's instructions. The core-level binding energies, $\mathrm{E}_{b}$, were calibrated using the Cls peak of $\mathrm{E}_{b}=285.0 \mathrm{eV}$.

\section{RESULTS}

The depth-profiles of the relative concentrations of the measured elements as a function of argon-ion-sputtering time for each amalgam and condition are shown in Figs. 1-6. The contribution from carbon contamination was minor and at the same magnitude for each experiment, so it is not included in the results ${ }^{1)}$. In both amalgams and all conditions, oxygen was enriched at the outer surface and drastically reduced at lower depths. The same was true for tin in the zinc-free amalgam. In contrast, silver and copper were depleted at the surface compared with the bulk concentration and increased at lower depths for both amalgams. A high concentration of mercury accumulated a few nm below the surface of amalgams in air, but was essentially constant with depth in water and saline.

\# ESCALAB MK-II, Vacuum Generator Scientific Ltd., Sussex, England, UK 
In the zinc-free amalgam, the environment seemed to have little effect on the surface film (Figs. 1, 3, and 5) and insignificant amounts of sodium and chlorine were found on the surface in saline (Fig. 5). On the contrary, in the zinc-containing amalgam, environment had significant effect on the surface (Figs. 2, 4, and 6). Sodium and chlorine were present in high concentrations in the layer formed in saline, thereby reducing the relative concentrations of all other elements (Fig. 6). While zinc decreased at lower depth in air, and to a certain extent in water, the zinc concentration remained constant in saline (Figs, 2, 4, and 6). In addition, the zinc concentration was lower in water and saline than in air.

Table 2 lists the core-level binding energies for silver, copper, zinc, and mercury before

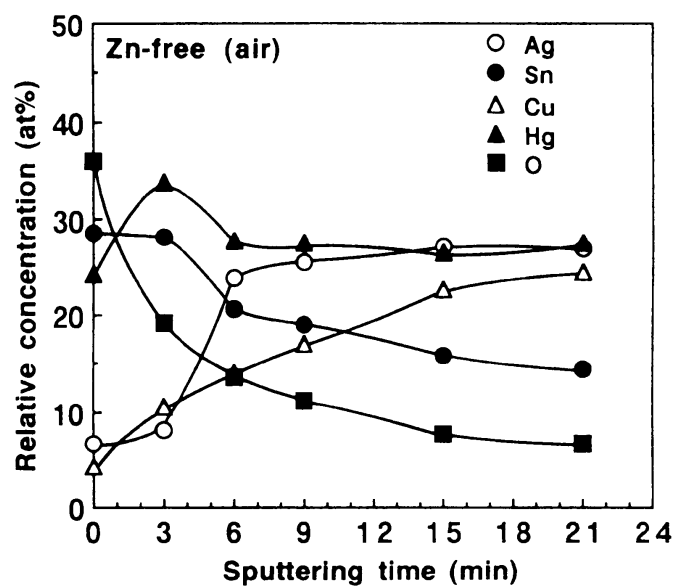

Fig. 1 The depth profiles for the relative concentrations of the elements in the zinc-free amlgam polished and aged in air.

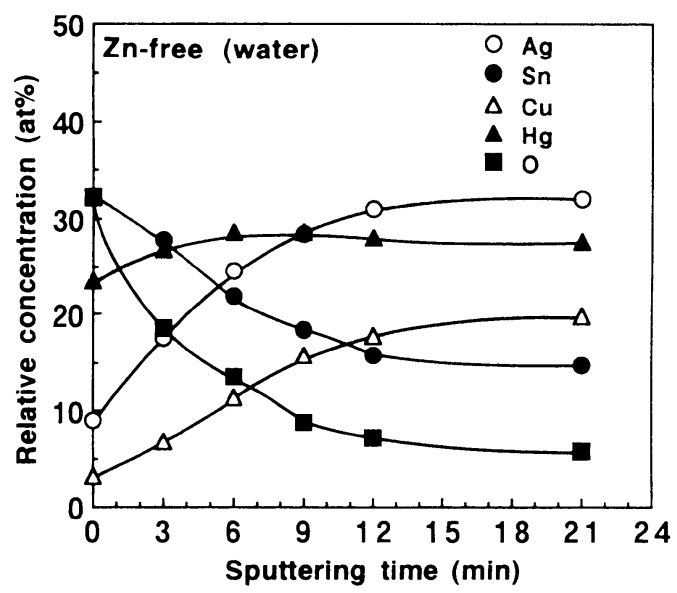

Fig. 3 The depth profiles for the relative concentrations of the elements in the zinc-free amlgam polished and aged in water.

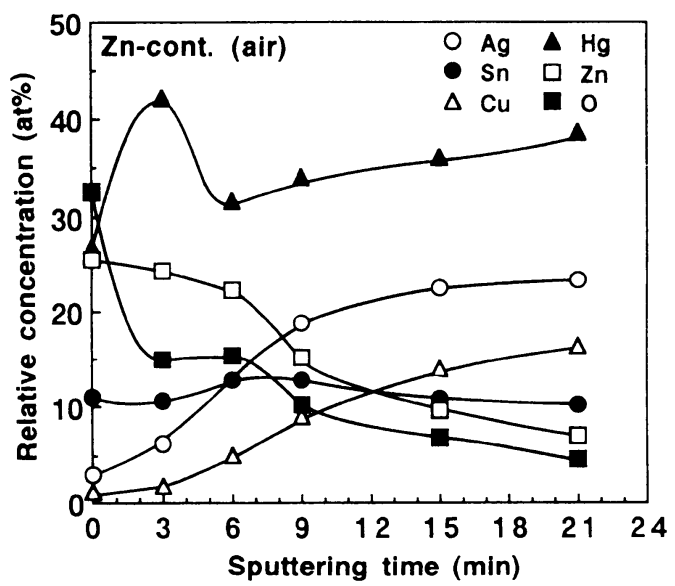

Fig. 2 The depth profiles for the relative concentrations of the elements in the zinccontaining amlgam polished and aged in air.

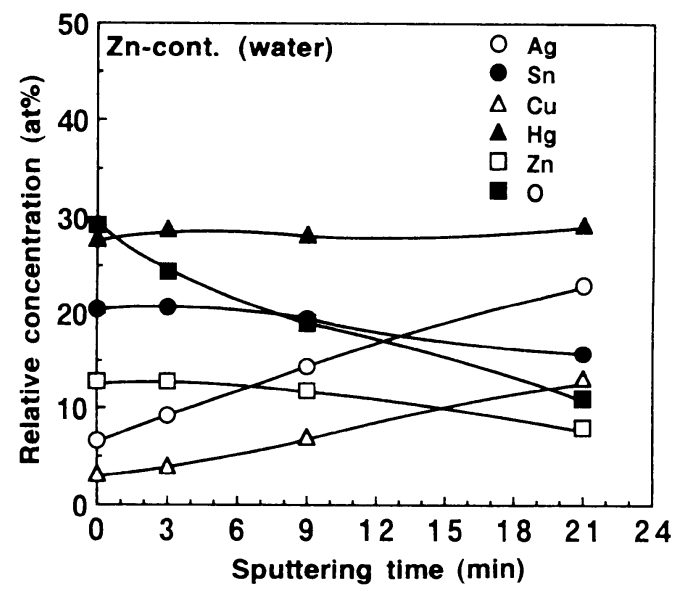

Fig. 4 The depth profiles for the relative concentrations of the elements in the zinccontaining amlgam polished and aged in water. 


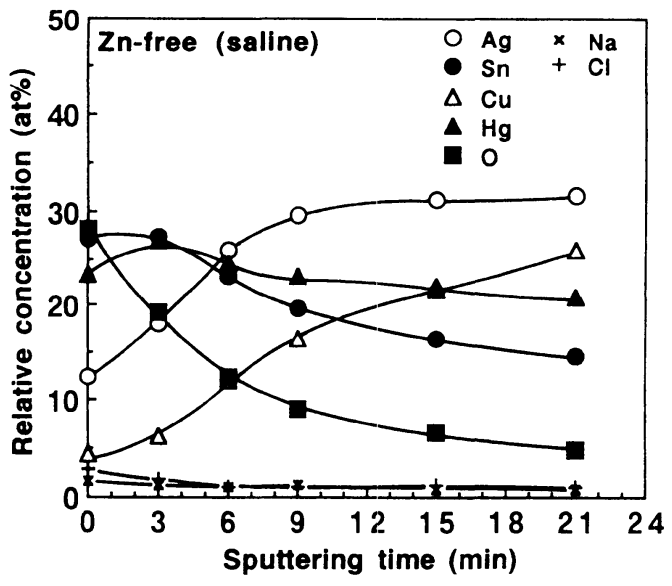

Fig. 5 The depth profiles for the relative concentrations of the elements in the zinc-free amlgam polished and aged in saline.

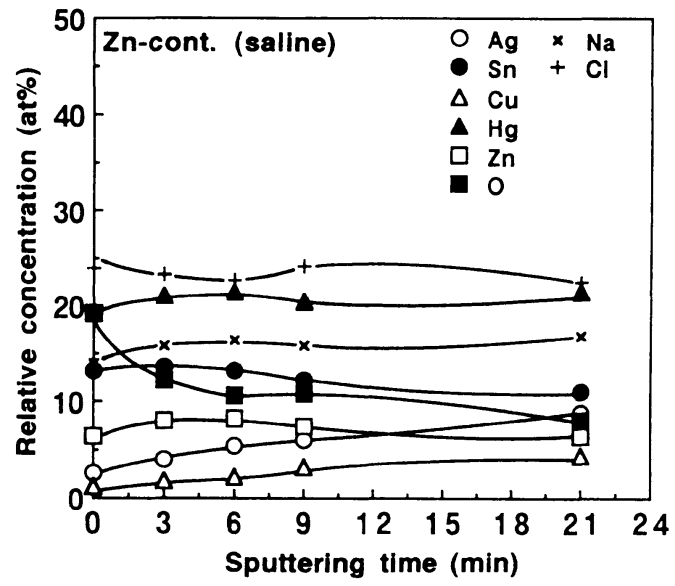

Fig. 6 The depth profiles for the relative concentrations of the elements in the zinccontaining amlgam polished and aged in saline.

Table 2 Core-level binding energies $(\mathrm{eV})$ of silver, copper, zinc, and mercury

\begin{tabular}{|c|c|c|c|c|c|c|c|}
\hline \multirow{2}{*}{$\begin{array}{l}\text { Element } \\
\text { and level }\end{array}$} & \multirow{2}{*}{$\begin{array}{l}\text { Sputtering } \\
\text { time (min) }\end{array}$} & \multicolumn{3}{|c|}{$\mathrm{Zn}$-free amalgam } & \multicolumn{3}{|c|}{$\mathrm{Zn}$-containing amalgam } \\
\hline & & Air & Water & Saline & Air & Water & Saline \\
\hline \multirow[t]{7}{*}{$\operatorname{Ag} 3 d_{5 / 2}$} & 0 & 368.4 & 368.4 & 368.3 & 368.3 & 368.5 & 368.5 \\
\hline & 3 & 368.4 & 368.4 & 368.4 & 368.3 & 368.5 & 368.5 \\
\hline & 6 & 368.0 & 368.4 & 368.4 & 368.2 & - & 368.5 \\
\hline & 9 & 368.0 & 368.4 & 368.4 & 368.2 & 368.5 & 368.5 \\
\hline & 12 & - & 368.4 & - & - & - & - \\
\hline & 15 & 368.0 & - & 368.4 & 368.2 & - & - \\
\hline & 21 & 368.0 & 368.4 & 368.4 & 368.2 & 368.4 & 368.5 \\
\hline \multirow[t]{7}{*}{$\mathrm{Cu} 2 \mathrm{p}_{3 / 2}$} & 0 & 933.1 & 933.1 & 933.1 & 932.7 & 933.2 & 933.3 \\
\hline & 3 & 933.0 & 933.1 & 933.1 & 932.8 & 933.2 & 933.3 \\
\hline & 6 & 932.8 & 933.0 & 933.1 & 932.7 & - & 933.2 \\
\hline & 9 & 932.8 & 933.1 & 933.1 & 932.6 & 933.1 & 933.2 \\
\hline & 12 & - & 932.9 & - & - & - & - \\
\hline & 15 & 932.6 & - & 933.0 & 932.5 & - & - \\
\hline & 21 & 932.6 & 933.0 & 933.0 & 932.4 & 933.0 & 933.1 \\
\hline \multirow[t]{7}{*}{$\mathrm{Zn} 2 \mathrm{p}_{3 / 2}$} & 0 & - & - & - & 1021.8 & 1022.1 & 1022.2 \\
\hline & 3 & - & - & 一 & 1021.5 & 1022.0 & 1022.2 \\
\hline & 6 & - & - & - & 1021.4 & - & 1022.1 \\
\hline & 9 & - & - & - & 1021.5 & 1022.0 & 1022.1 \\
\hline & 12 & - & - & - & - & - & - \\
\hline & 15 & - & - & - & 1021.5 & - & - \\
\hline & 21 & - & - & - & 1021.5 & 1022.0 & 1022.1 \\
\hline \multirow[t]{7}{*}{$\mathrm{Hg} 4 \mathrm{f}_{7 / 2}$} & 0 & 100.1 & 100.1 & 100.0 & 100.0 & 100.1 & 100.0 \\
\hline & 3 & 99.8 & 100.0 & 100.0 & 99.8 & 100.1 & 100.1 \\
\hline & 6 & 99.8 & 100.0 & 100.0 & 100.1 & - & 100.1 \\
\hline & 9 & 99.8 & 100.1 & 100.0 & 100.1 & 100.1 & 100.1 \\
\hline & 12 & - & 100.0 & - & - & - & - \\
\hline & 15 & 99.8 & - & 100.1 & 100.0 & - & - \\
\hline & 21 & 99.8 & 100.1 & 100.1 & 100.0 & 100.1 & 100.1 \\
\hline
\end{tabular}


Table 3 Published binding energies

\begin{tabular}{|c|c|c|c|}
\hline Elements and level & $\begin{array}{l}\text { Binding energy of } \\
\text { metallic state }(\mathrm{eV})\end{array}$ & Oxide & $\begin{array}{c}\text { Binding energy of } \\
\text { oxide state }(\mathrm{eV})\end{array}$ \\
\hline \multirow[t]{2}{*}{$\operatorname{Ag} 3 d_{5 / 2}$} & $367.9^{9)}$ & $\mathrm{Ag}_{2} \mathrm{O}$ & $386.2^{10)}$ \\
\hline & & $\mathrm{AgO}$ & $367.4^{10)}$ \\
\hline \multirow[t]{2}{*}{$\operatorname{Sn} 3 d_{5 / 2}$} & $484.8^{9)}$ & $\mathrm{SnO}$ & $486.9^{10)}$ \\
\hline & & $\mathrm{SnO}_{2}$ & $486.9^{10)}$ \\
\hline \multirow[t]{2}{*}{$\mathrm{Cu} 2 \mathrm{p}_{3 / 2}$} & $932.5^{9)}$ & $\mathrm{Cu}_{2} \mathrm{O}$ & $933.0^{10)}$ \\
\hline & & $\mathrm{CuO}$ & $934.0^{10)}$ \\
\hline $\mathrm{Zn} 2 \mathrm{p}_{3 / 2}$ & $1021.7-1021.8^{11,12)}$ & $\mathrm{ZnO}$ & $1022.1^{10)}$ \\
\hline $\mathrm{Hg} 4 \mathrm{f}_{7 / 2}$ & $99.6-99.9^{11,12)}$ & $\mathrm{HgO}$ & $101.9^{10)}$ \\
\hline
\end{tabular}

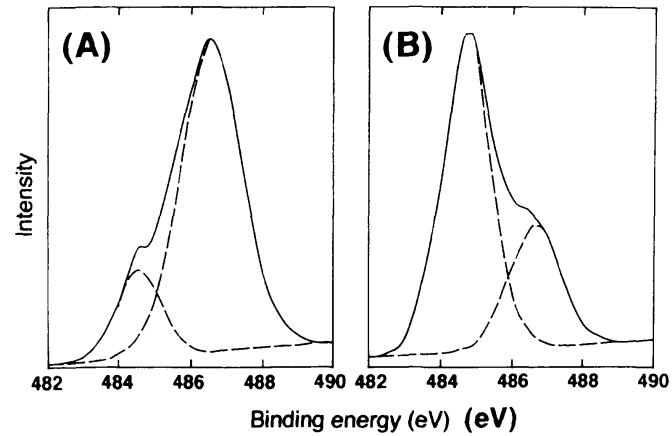

Fig. $7 \quad$ Sn3d $d_{5 / 2}$ XPS spectra obtained from the zinc-free amalgam polished and aged in air: (A) no sputtering and (B) 21-min sputtering.

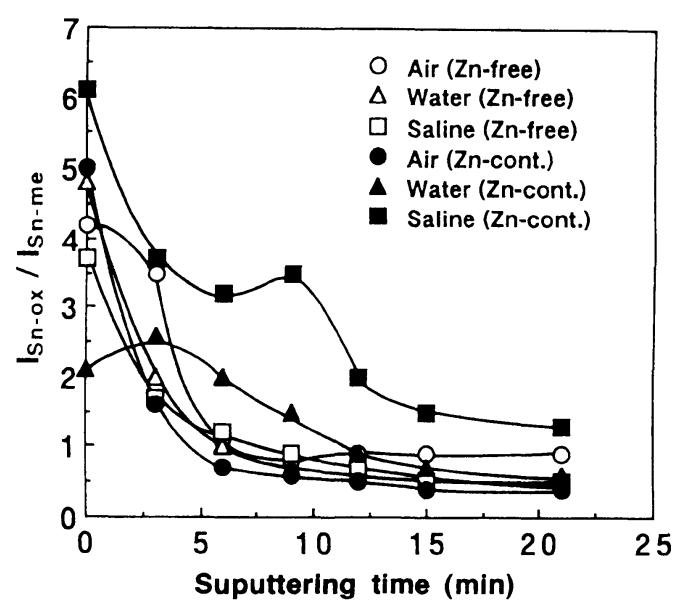

Fig. 8 Change in the ratio of the integrated intensity of $\mathrm{Sn} 3 \mathrm{~d}_{5 / 2}$ spectrum originating from oxide-state $\left(\mathrm{I}_{\mathrm{sn-ox}}\right)$ to that from metallic state $\left(\mathrm{I}_{\mathrm{sn}-\mathrm{me}}\right)$ as sputtering time.

and after argon-ion-sputtering. Also, published binding energy data are summarized in Table 3 for comparison. Since $S n 3 d_{5 / 2}$ XPS spectra have shoulders of the higher or lower energy side, the spectra were decomposed into two spectra (Fig. 7), one originating from the metallic state and the other from the oxide state, according to Table 3 . The binding energies in the metallic and oxide states were $484.8 \mathrm{eV}$ and $486.9 \mathrm{eV}$, respectively, and were constant independent of the sputtering time. The ratios of the integrated intensity of oxide-statespectrum to that of metallic-state-spectrum for each condition as a function of sputtering time are shown in Fig. 8. In this figure, the larger the ratio is, the larger the magnitude of the oxidation of tin. The figure indicates that tin is more highly oxidized in the outer surface for all conditions.

\section{DISCUSSION}

The XPS data were obtained from areas (approximately $3 \mathrm{~mm}^{2}$ ) which are much larger than 
the extent of any single phase, and therefore represent an average over all phases of the amalgams.

Tin in the zinc-free amalgam in all three environments and zinc in the zinc-containing amalgam in air were enriched at the outer surface and depleted at the lower depths (Figs. 1 -3 and 5). Also, oxygen was reduced at the lower depths (Figs. 1-6). These data indicate that tin and zinc had formed oxides and/or hydroxides near the surface. It is probable that the large amount of tin and zinc found in the outer surface was the result of the migration of these elements to the amalgam surface where they subsequently combined with oxygen. Fig. 8 shows that tin was more oxidized in the outer surface of the amalgams. On the other hand, it could not be determined whether or not zinc was oxidized because the core-level binding energies of zinc in the metallic-state and zinc in the oxide-state were too similar to be resolved. However, because the free energy for the formation of $\mathrm{ZnO},-318.8 \mathrm{~kJ} / \mathrm{mol}$, is lower than that of $\mathrm{SnO},-257.9 \mathrm{~kJ} / \mathrm{mol}$, and higher than that of $\mathrm{SnO}_{2},-521.6 \mathrm{~kJ} / \mathrm{mol}$, at $25^{\circ} \mathrm{C}^{13)}$, and because zinc in the zinc-containing amalgam in air was enriched in the outer surface along with oxygen, it is likely that the zinc was in an oxidized form, similar to tin. Therefore, as in the previous study ${ }^{1)}$, it can be concluded that tin and zinc, particularly tin in the zinc-free amalgam and zinc in the zinc-containing amalgam, are the dominant elements governing the formation of the surface layer of amalgams in air. Both elements, but especially zinc, combine readily with oxygen ${ }^{14}$.

In contrast, the amount of zinc at the surface of the zinc-containing amalgam in water only slightly decreased with depth, while zinc was constant with depth in saline. This was surprising, because according to the binding energy data (Tables 2 and 3), zinc should be oxidized in water and saline, even though the differences in the core-level binding energy between the metallic-state and the oxide-state were in the range of experimental error. The fact that zinc did not accumulate at the outer surface of the amalgam in spite of its likely combination with oxygen in saline and water, may be explained by the fact that zinc readily dissolves into saline and water, thereby depleting its concentration at the surface ${ }^{15}$. This is especially true in saline. That is, due to its high rate of dissolution in aqueous environments, zinc is expected to dissolve from the surface of the zinc-containing amalgam in water and saline, causing its concentration of the surface to be similar to that in the bulk. The dissolution of zinc from the amalgam seems to be in conflict with the oxidation of zinc. One possible explanation is that zinc atoms in the amalgam in water and saline experiments are more strongly oxidized during washing by deionized water, than those in air experiment.

The behavior of silver and copper is entirely different from that of tin and zinc, $i$. $e$. only small amounts of silver and copper were present in the outer surface of the amalgams (Figs. 1-6). The concentration of silver and copper increased at the lower depth, except in the zinc -containing amalgam in saline. The amount of an element in the outer surface layer depends on its relative ease of oxidation. Since tin and zinc atoms apparently migrate to the surface and preferentially combine with oxygen, the relative concentration of silver and copper in the surface layers must be correspondingly decreased. The core-level binding energies of silver and copper were slightly decreased at lower depths in air (Table 3). However, the magnitudes of the changes in the core-level binding energy of silver and copper were within the range of experimental error, so it is not possible to discuss the oxidation state 
of these elements at the different depths. On the other hand, it is improbable that silver atoms in both amalgams form $\mathrm{AgCl}$ with saline. Most of silver atoms in amalgams exist as a phase of $\gamma_{1}\left(\mathrm{Ag}_{2} \mathrm{Hg}_{3}\right)$ and the free energy for the formation is $-644.3 \mathrm{~kJ} / \mathrm{mol}^{16)}$, while that for the formation of $\mathrm{AgCl}$ is $-109.9 \mathrm{~kJ} / \mathrm{mol}^{13)}$ at $25^{\circ} \mathrm{C}$. In other words, most of silver atoms in amalgam do not dissociate from mercury to combine with chlorine. In addition, the free energy for the formation of $\mathrm{Ag}_{2} \mathrm{Hg}_{3}$ is lower than that of $\mathrm{ZnO},-318.8 \mathrm{~kJ} / \mathrm{mol}$ at $25^{\circ} \mathrm{C}$, that of $\mathrm{SnO},-257.9 \mathrm{~kJ} / \mathrm{mol}$, and $\mathrm{SnO}_{2},-521.6 \mathrm{~kJ} / \mathrm{mol}^{13}$, and that of $\mathrm{AgCl}$ is higher than those of $\mathrm{ZnO}, \mathrm{SnO}$, and $\mathrm{SnO}_{2}$. Therefore, the maintenance of $\gamma_{1}\left(\mathrm{Ag}_{2} \mathrm{Hg}_{3}\right)$ and formation of $\mathrm{ZnO}, \mathrm{SnO}$, and $\mathrm{SnO}_{2}$ rather than the formation of $\mathrm{AgCl}$ are preferential and only small amounts of silver was present in the outer surface of the amalgams.

The behavior of mercury is distinctly different from that of the other elements. As seen in Tables 2 and 3, the core-level binding energies of mercury measured in this study were much smaller than that of $\mathrm{HgO}$. Also, the binding energies were not affected by argon-ionsputtering. Therefore, it can be concluded that the mercury at the surface had not combined with oxygen. This is consistent with the fact that mercury is the noblest element in the amalgams ${ }^{17)}$ and would not be expected to be oxidized. This experiment also showed that the mercury concentration within the surface layer of the specimen was similar to that in the bulk (Table 1). Furthermore, a mercury-concentrated layer was present a few nm below the surface for the amalgams in air. It is possible that the mercury-concentrated layer was formed during polishing due to localized heating effects. The surface layer that grew during aging formed over it, thus the mercury rich layer was displaced to a lower depth.

The depth-profiles of the concentrations of the elements in the zinc-free amalgam in the three environments were similar to one another, with only minor discrepancies. Therefore, the environment did not affect the composition of the surface layer formed on the zinc-free amalgam. In addition, for the zinc-containing amalgam in air, the depth-profiles were similar to those for the zinc-free amalgam. However, the depth-profiles of the zinc-containing amalgam in water and saline were different from the others in that the concentration of zinc was relatively constant with depth in the solutions.

\section{CONCLUSIONS}

The aging environment affected the surface layer found on the zinc-containing amalgam, but did not affect the layer formed on the zinc-free amalgam. This indicates that zinc is the most significant element in amalgam in terms of its reactivity toward the environment. Mercury behaved independent of the other elements, and its concentration was essentially independent of depth. Mercury existed in the metallic state in the surface layer on both amalgams.

\section{ACKNOWLEDGMENTS}

This study was supported in part by Research Grant DE07644 from the National Institute of Dental Research, National Institutes of Health, Bethesda, MD 20892, USA. Also, we would like to thank GC Corporation for supply of amalgam alloys. 


\section{REFERENCES}

1) Hanawa, T., Takahashi, H., Ota, M., Pinizzotto, R. F., Ferracane, J. L. and Okabe, T.: Surface characterization of amalgams using x-ray photoelectron spectroscopy, J Dent Res 66 : 1470-1478, 1987.

2) Okabe, T., Mafiana, P. and Ferracane, J. L.: Mercury release under simulated chewing abrasion of amalgams, Transactions of the Third World Biomaterials Congress, Kyoto, Japan, 1988, p. 256.

3) Hanawa, T., Matsuda, K., Ota, M., Shimokobe, H., Ferracane, J. L., Nelson,P. and Okabe, T.: Thermal behavior of amalgams under argon atmosphere, J Dent Res 65 : 192, 1986.

4) Tsutsumi, S., Nakamura, M., Ferracane, J. L., Schiller, T. L., Hanawa, T. and Okabe, T.: Thermal analysis of amalgams, Dent Mater 4 : 307-311, 1988.

5) Ferracane, J. L., Hanawa, T. and Okabe, T. : Effectiveness of oxide films in reducing mercury release from amalgams, J Dent Res 71: 1151-1155, 1992.

6) Okabe, T., Ferracane, J. L., Cooper, C., Matsumoto, H. and Wagner, M. : Dissolution of mercury from amalgam into saline solution, $J$ Dent Res $66: 33-37,1987$.

7) Ferracane, J. L., Mafiana, P., Cooper, C. and Okabe, T.: Time-dependent dissolution of amalgam into saline solution, . J Dent Res 66 : 1331-1335, 1987.

8) Practical surface analysis, 2nd ed., Vol. 1, Briggs, D. and Seah, M. P. Eds., John Wiley \& Sons, New York, 1990.

9) Fuggle, J. C. and Mårtensson, N. : Core-level binding energies in metals, J Electron Spectrosc 21 : 275 $-281,1980$.

10) Hanawa, T., Echizenya. T., Kondo, S., Ohkawa, S., Sugawara, T. and Ota, M. : Useful data of binding energy for x-ray photoelectron spectroscopy of dental metals and alloys, Hokkaido J Dent Sci 11: 27 -31, 1990. (in Japanese)

11) Wagner, C. D., Riggs, W. M., Davis, L. E., Moulder, J. F. and Muilenberg, G. E. : Handbook of X-ray photoelectron spectroscopy, Perkin Elmer Corp., Eden Prairie, 1979.

12) Wagner, C. D.: Photoelectron and Auger energies and the Auger parameter: a data set, Practical surface analysis, 2nd ed., Vol. 1, Briggs, D. and Seah, M. P. Eds., John Wiley \& Sons, New York, 1990, pp. 595-634.

13) CRC Handbook of Chemistry and Physics, 67th ed., Weast, R. C. ed., CRC Press, Inc., Boca Raton, Florida, 1986, pp. D51-D93.

14) Gaskel, D. R. : Introduction to metallurgical thermodynamics, McGraw-Hill, New York, 1973, p. 269.

15) Gjerdet, N. R. and Berge, M. : Liberation of copper, zinc, and cadmium from different amalgams, Acta Odontol Scand 41 : 217-220, 1983.

16) Reynolds, Jr., C. L. and Baker, Jr., R. E. : Comparison of phase stability in $\mathrm{Ag}_{2} \mathrm{Hg}_{3}$, and $\mathrm{Sn}_{7-8} \mathrm{Hg}$ as reflected in the calculation of potential energy, $J$ Chem Phys 58:1774-1775, 1973.

17) Phillips, R. W. : Science of Dental Materials, 8th ed., W. B. Saunders Co., Philadelphia, 1982, p. 293. 


\section{大気中, 水中, 生理食塩水中においてアマルガム上に生成する表面層の組成}

塙 隆夫, Bruce E. Gnade ${ }^{1}$, Jack L. Ferracane ${ }^{2}$, 岡部 徹 ${ }^{3}$, 亘理文夫

\section{北海道大学歯学部歯科理工学講座}

${ }^{1}$ Materials Science Laboratory, Texas Instruments

${ }^{2}$ Department of Dental Materials Science, The Oregon Health Science University,

Shcool of Dentistry

${ }^{3}$ Department of Biomaterials Science, Baylor College of Dentistry

歯科用アマルガムからの水銀の蒸発あるいは溶出を支 配していると考えられるアマルガムの表面層の組成を決 定するために, 大気中, 純水中および生理食塩水中にお いて研磨して保存したときに亜鉛を含有しないアマルガ ムと亜鉛を含有するアマルガムの上に生成する表面層 を, X 線光電子分光 (XPS) によって解析した. XPS の 結果は, 覀鉛を含有するアマルガムの表面層の組成は,
アマルガムを研磨して保存した環境の影響を受けること を示したが，覀鉛を含有しないアマルガムでは環境によ る影響を受けなかった. また, アマルガムの構成元素の うち，亜鉛は環境に対する反応性がもっとも高く水中あ るいは生理食塩水中に優先的に溶出した，水銀原子は表 面層中では金属状態で存在していた。

ビスファンクショナルタイプの加水分解性基をもつシランによる表面処理効果

$$
\begin{aligned}
& \text { 倉田茂昭, 山崎 } \text { 升 }^{1} \\
& \text { 神奈川歯科大学化学教室 } \\
& { }^{1} \text { 東京工業大学名誉教授 }
\end{aligned}
$$

1，6-ピス（トリクロロシリル）へキサン (BISHEX) および 1,8 -ビス(トリクロロシリル)オクタン

(BISOCT) のようなピスファンクショナルシランを用 い, シラン処理層の架橋構造と処理効果の関係を処理ガ ラス面に対するレジンの接着性から検討した。その結果， BISHEX およびBISOCT で処理した場合の接着強さ
は, $37^{\circ} \mathrm{C}$ 水中保存後, いずれも約 $20 \mathrm{MPa}$ で, それらシ ランは接着剤レジンと反応する二重結合がないにもかか わらず高い值を示した. BISHEX と 3-メタクリロキシ プロピルトリクロロシラン (3-MPST) の混合による処 理は, 3-MPST 単独処理に比べ, 優れた接着耐水耐久性 を示した。

歯科磁性アタッチメントシステムにおける異種金属接触腐食について 飯室隆子フロレンチーナ, 米山隆之, 奥野 攻 ${ }^{1}$

\section{東京医科歯科大学 医用器材研究所 金属材料部門}

${ }^{1}$ 東北大学歯学部 歯科理工学講座

口腔内でインプラントや磁性アタッチメントなどを用 いる場合にはどうしても異なる金属材料が同時に，接触 されあるいは結合されて用いられることになる．このよ うな場合，それぞれが単独で用いられる場合と腐食挙動 が異なってくると考えられる。そこで磁性アタッチメン
トとインプラントが用いられた場合を考え，磁性ステン レス鋼, チタン, 白金加金, 金銀パラジウム合金, なと゚ を単独と，それぞれ 2 つづつ組み合わされた時の耐食性 を $1 \%$ 乳酸の腐食溶出試験と電位/電流密度曲線試験で 調べ検討した. 